\title{
Hubungan Asupan Protein, Fe, Vitamin C Serta Ketepatan Konsumsi Zat Tannin Dan Kafein Terhadap Kadar Hemoglobin Ibu Hamil Trimester III Di Puskesmas Kota Yogyakarta
}

Yuliantisari Retnaningsih ${ }^{1}$, Ika Agustina Sulistyani ${ }^{2}$, Yuliasti Eka Purnamamingrum ${ }^{2}$, Margono $^{2}$ Dwiana Estiwidani ${ }^{2}$

1.Jurusan Kebidanan Poltekkes Kemenkes Yogyakarta, Jalan Mangkuyudan MJ III/304, Yogyakarta 55143, yuliantisarir@gmail.com

2. Jurusan Kebidanan Poltekkes Kemenkes Yogyakarta, Jalan Mangkuyudan MJ III/304, Yogyakarta 55143,

\begin{tabular}{|c|c|}
\hline \multirow[b]{2}{*}{$\begin{array}{l}\text { Kata kunci: } \\
\text { Hemoglobin } \\
\text { kafein } \\
\text { protein } \\
\text { vitamin c } \\
\text { zat besi } \\
\text { zat tannin }\end{array}$} & ABSTRAK \\
\hline & 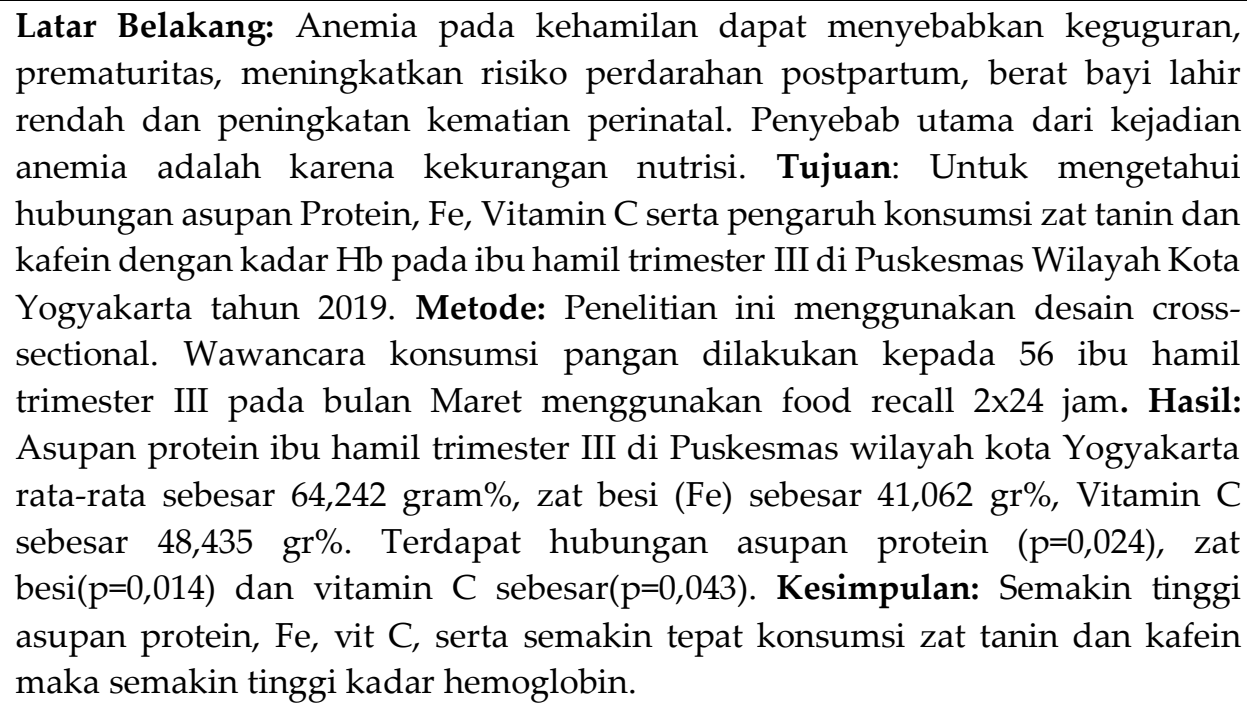 \\
\hline & ABSTRACT \\
\hline $\begin{array}{l}\text { Key word: } \\
\text { Haemoglobin } \\
\text { Caffeine } \\
\text { Protein } \\
\text { Vitamin C } \\
\text { Iron } \\
\text { Tannin }\end{array}$ & $\begin{array}{l}\text { Background: The relationship between protein, iron, vitamin C intake and the accuracy } \\
\text { of tannin and caffeine consumption on hemoglobin levels of third trimester pregnant } \\
\text { women at Yogyakarta City Health Center. Anemia in pregnancy can cause miscarriage, } \\
\text { prematurity, increased risk of postpartum hemorrhage, low birth weight and increased } \\
\text { perinatal mortality. The main cause of anemia is lack of nutrition. Objectives: To } \\
\text { determine the relationship between protein, iron, vitamin C intake and the effect of tannin } \\
\text { and caffeine consumption on Hb levels in third trimester pregnant women at Yogyakarta } \\
\text { City Regional Health Center in } 2019 \text {. Method: This was a cross-sectional design. Food } \\
\text { consumption interviews were conducted to } 56 \text { pregnant women in the third trimester in } \\
\text { March using a } 2 x 24 \text { hour food recall. Result: Protein intake of third-trimester pregnant } \\
\text { women in the Health City Center in Yogyakarta were } 64,242 \text { gram } \% \text {, iron (Fe) of } \\
41,062 \text { gr\%, Vitamin C amounting to } 48.435 g r \% \text { in average. There was significant } \\
\text { relationship between protein intake ( } p=0.024) \text {, iron ( } p=0.014 \text { ) and vitamin C } \\
\text { (p=0.043). Conclusion: The higher intake of protein, Fe, vit } C \text {, and the more appropriate } \\
\text { consumption of tannins and caffeine, the higher the hemoglobin level. }\end{array}$ \\
\hline
\end{tabular}

This is an open access article under the CC-BY-SA license. 


\section{Pendahuluan}

Kehamilan merupakan kondisi alamiah yang unik karena meskipun bukan penyakit, tetapi seringkali menyebabkan komplikasi akibat perubahan anatomik serta fisiologik dalam tubuh ibu. Salah satu perubahan fisiologik yang terjadi adalah perubahan hemodinamik yang bisa menyebabkan kelainan hematologik dalam kehamilan. Kelainan hematologik yang termasuk penyebab terbanyak yaitu anemia.[1] Anemia adalah suatu keadaan dimana kadar Hemoglobin $(\mathrm{Hb})$ dalam darah kurang dari normal, yang berbeda untuk setiap kelompok umur dan jenis kelamin. Faktor risiko anemia itu sendiri yang sangat fatal antara lain risiko keguguran, kematian, prematuritas dan berat bayi lahir rendah.[2] Sejauh ini upaya dalam mengurangi kejadian anemia di seluruh dunia masih mengalami kegagalan, hal tersebut membuat banyak wanita yang menderita gangguan kesehatan dan menurunnya kualitas hidup.[3]

Data World Health Organization (WHO) tahun 2016 menunjukkan bahwa anemia mempengaruhi 33\% wanita usia reproduktif (sekitar 61 juta wanita antara 15 dan 49 tahun). WHO mengambil langkah tindak lanjut untuk mencapai target Majelis Kesehatan Dunia yaitu pengurangan $50 \%$ anemia pada wanita usia reproduksi tahun di tahun 2025. Prevalensi anemia tertinggi salah satunya di Asia yatu lebih dari 35\%.3 Profil kesehatan DIY 2017 menyebutkan Prevalensi anemia ibu hamil di Indonesia itu sendiri sebesar 50-63\% khasus.[4] sedangkan prevalensi anemia ibu hamil di DIY tahun 2015 itu sendiri sebesar 14,85\%, mengalami kenaikan pada tahun 2016 menjadi 16,09\%, dan kembali turun menjadi 14,32\% pada tahun 2017.[5] Data tersebut dapat dilihat lebih rinci gambaran angka kejadian di setiap kabupaten pada tabel 1 berikut:

Tabel 1. Kasus Ibu Hamil dengan Anemia di DIY Tahun 2015-2017

\begin{tabular}{clrrc}
\hline & & \multicolumn{3}{c}{ Tahun } \\
\cline { 3 - 5 } No. & Kabupaten/Kota & $\mathbf{2 0 1 5}$ & $\mathbf{2 0 1 6}$ & $\mathbf{2 0 1 7}$ \\
\hline 1. & Kulon Progo & 13,00 & 13,00 & 12,88 \\
2. & Bantul & 19,21 & 19,91 & 16,32 \\
3. & Gunungkidul & 9,87 & 24,86 & 16,77 \\
4. & Sleman & 10,36 & 9,00 & 8,06 \\
\hline Sumber:[4][5][6] & & &
\end{tabular}

Kekurangan nutrisi merupakan faktor penyebab terbesar anemia pada ibu hamil. Kekurangan nutrisi tersebut menjadi masalah yang sering timbul pada negara perpendapatan menengah dan rendah.[3] Kebiasaan ibu hamil mengkonsumsi makanan dan minuman yang beragam, seperti contoh minum teh dan kopi juga mempengaruhi status gizi khususnya kadar $\mathrm{Hb}$ ibu tersebut.[7] Selama hamil kebutuhan gizi meningkat dibandingkan dengan kebutuhan sebelum hamil. Pada trimester II kehamilan terjadi penurunan konsentrasi $\mathrm{Hb}$ yang mencapai titik terendah dan akan meningkat kembali pada trimester ke III. Perubahan ini bukanlah perubahan patologis, tetapi merupakan perubahan fisiologis kehamilan yang diperlukan untuk perkembangan janin. Kadar $\mathrm{Hb}$ yang rendah akan mempengaruhi kemampuan sistem maternal untuk memindahkan oksigen dan nutrisi yang cukup ke janin. Memasuki trimester ke III kadar $\mathrm{Hb}$ akan kembali meningkat, dimana trimester ke III adalah masa saat ibu mempersiapkan kondisi kesehatan baik ibu dan janin. Ibu diharapkan lebih memperhatikan konsumsi makan untuk meningkatkan kadar $\mathrm{Hb}$ agar sesuai standar kadar $\mathrm{Hb}$ ibu hamil. Keadaan anemia ibu hamil saat akan bersalin mempengaruhi proses persalinan, karena anemia salah satu faktor terjadinya perdarahan post partum.[8]

Penelitian lain mengenai kadar $\mathrm{Hb}$ pada ibu hamil Trimester II dan III diperoleh hasil bahwa tingkat kecukupan energi, protein, zat besi, vitamin $C$ dan asupan suplemen tablet besi memiliki 
hubungan yang signifikan secara statistik dengan kadar hemoglobin ibu hamil Trimester II dan III.[9] Hasil penelitian itu didapatkan tidak sejalan dengan hasil penelitian Rachmawati Oktavia Mandasari di Mojolaban Kabupaten Sukoharjo bahwa tidak ada hubungan antara asupan protein dengan kadar hemoglobin, tidak ada hubungan antara asupan zat besi dengan kadar hemoglobin, tidak ada hubungan antara asupan vitamin $C$ dengan kadar hemoglobin.[10] Berdasarkan latar belakang tersebut maka penulis tertarik melakukan penelitian bagaimana hubungan asupan protein, Fe, vitamin $\mathrm{C}$ serta pengaruh zat tanin dan kafein terhadap kadar hemoglobin pada ibu hamil trimester III dengan anemia di Puskesmas Wilayah Kota Yogyakarta tahun 2019.

\section{Metode}

Penelitian ini studi observasional dengan desain cross sectional melihat asupan protein, Fe, vitamin $C$ serta pengaruh zat tanin dan kafein terhadap kadar hemoglobin pada ibu hamil trimester III dengan anemia.[11] Tempat penelitian di Puskesmas Wilayah Kota Yogyakarta yaitu Puskesamas Mantrijeron dan Puskesmas Tegalrejo. Penelitian ini dilakukan mulai bulan Januari sampai dengan Maret 2019. Sampel penelitian ini adalah ibu hamil trimester III dengan besar sampel 56 orang, teknik pengambilan sampel dengan purposive sampling. Adapun kriteria yang peneliti gunakan adalah kriteria Inklusi yaitu Ibu yang bersedia menjadi responden dengan menandatangani informed consent dan kriteria eksklusi yaitu Ibu hamil dengan penyakit (Malaria, TBC, HIV/AIDS, dan HepatitisB). Pada penelitian ini dilakukan pengamatan tentang konsumsi protein, $\mathrm{Fe}$, vitamin $\mathrm{C}$, tanin dan kafein, dan kadar $\mathrm{Hb}$ pada ibu hamil trimester III.[11] Data yang digunakan data primer dan data sekunder. Data primer yang digunakan peneliti yaitu data yang diperoleh langsung dari responden. Data primer yang didapat yaitu umur, berat badan, konsumsi protein, zat besi (Fe), vitamin $\mathrm{C}$, zat tanin dan kafein. Data sekunder yang digunakan peneliti yaitu data yang diperoleh dari buku register ANC tentang jumlah ibu hamil trimester III di daerah wilayah Kota Yogyakarta. Pengumpulan data primer dilakukan dengan menggunakan instrumen penelitian berupa kuesioner food recall 2x24 jam yang dijawab langsung oleh responden dan untuk data ibu hamil trimester III, peneliti menggunakan buku register ANC dan data kadar Hb.. Setelah data didapatkan dari semua responden yang sudah didatangi peneliti mengolah data. Analisis data menggunakan uji Person Product Moment untuk mengetahui hubungan zat besi, vitamin $C$ dan protein dengan kadar hemoglobin dan uji Independent T-test untuk mengetahui pengaruh asupan tannin dan kafein terhadap kadar hemoglobin. Data sebelumnya sudah diuji normalitas, dan didapatkan hasil berdistribusi normal.

\section{Hasil Dan Pembahasan}

Distribusi frekuensi karakteristik responden pada penelitian meliputi umur, berat badan dan status anemia.

Berdasar tabel 2 diketahui mayoritas responden pada kelompok umur 19-29 tahun (60,7 \%), Berdasarkan karakteristik berat badan mayoritas responden pada kelompok berat badan $>55 \mathrm{~kg}$ $(71,4 \%)$ dan dari kadar hemoglobin mayoritas responden dengan status tidak anemia $(73,2 \%)$. 
Tabel 2. Distribusi Frekuensi Ibu Hamil Trimester III Berdasarkan Umur, berat badan dan status anemia responden.

\begin{tabular}{ccc}
\hline \multicolumn{1}{c}{ Karakteristik } & F & \% \\
\hline Umur & 2 & 3,6 \\
a. 16-18 tahun & 34 & 60,7 \\
b. $19-29$ tahun & 20 & 35,7 \\
c. $30-49$ tahun & & \\
\hline Berat badan & 9 & 16,1 \\
a. $<50 \mathrm{~kg}$ & 7 & 12,5 \\
b. $50-55 \mathrm{~kg}$ & 40 & 71,4 \\
c. $>55 \mathrm{~kg}$ & & \\
\hline Status anemia & 15 & 26,8 \\
a. Tidak anemia & 41 & 73,2 \\
b. Anemia & &
\end{tabular}

Tabel 3. Rerata kadar hemoglobin, asupan protein, zat besi dan vitamin $\mathrm{C}$ responden

\begin{tabular}{lccc}
\hline Variabel dependen & Min & Max & Mean \pm SD \\
\hline Kadar $\mathrm{Hb}$ & 5,4 & 12,6 & $9,862 \pm 1,5834$ \\
\hline Protein & 11,9 & 115,0 & $64,242 \pm 24,4611$ \\
\hline Zat Besi & 2,1 & 300,4 & $41,062 \pm 60,3902$ \\
\hline Vitamin C & 3,6 & 237,4 & $48,435 \pm 50,0566$ \\
\hline
\end{tabular}

Berdasar tabel 3 diketahui rerata kadar hemoglobin 9,86 gr/dl, asupan protein 64,24 ,zat besi dan vitamin C 48,43 .

Tabel 4. Analisis hubungan asupan Protein, zat besi (Fe) dan vitamin $\mathrm{C}$ dengan kadar Hemoglobin

\begin{tabular}{|c|c|c|c|c|c|c|}
\hline \multirow{3}{*}{$\begin{array}{l}\text { Asupan } \\
\text { nutrisi }\end{array}$} & \multicolumn{4}{|c|}{ Kadar HB } & \multirow{3}{*}{$\mathbf{r}$} & \multirow{3}{*}{$\mathbf{P}$} \\
\hline & \multicolumn{2}{|c|}{ Anemia } & \multicolumn{2}{|c|}{ Tidak Anemia } & & \\
\hline & $\mathbf{N}$ & $\%$ & $\mathbf{n}$ & $\%$ & & \\
\hline \multicolumn{7}{|l|}{ Protein } \\
\hline a. Kurang & 25 & 83,33 & 5 & 16,67 & 0,300 & 0,024 \\
\hline b. Cukup & 16 & 50,00 & 10 & 50,00 & & \\
\hline \multicolumn{7}{|l|}{ Zat Besi (Fe) } \\
\hline a. Kurang & 37 & 77,08 & 11 & 22,92 & 0,327 & 0,014 \\
\hline b. Cukup & 4 & 50,00 & 4 & 50,00 & & \\
\hline \multicolumn{7}{|l|}{ Vitamin C } \\
\hline a. Kurang & 28 & 68,29 & 13 & 31,71 & $-0,272$ & 0,043 \\
\hline b. Cukup & 13 & 86,67 & 2 & 13,33 & & \\
\hline
\end{tabular}

Berdasar tabel 4 diketahui terdapat hubungan bermakna asupan protein, zat besi (Fe) dan vitamin $C$ dengan kadar hemogobin $(\mathrm{p}<0,05)$. 
Tabel 5. Analisis komparatif ketepatan asupan Zat Tanin dan Kafein terhadap Kadar Hemoglobin Ibu Hamil Trimester III di Puskesmas Wilayah Kota Yogyakarta Tahun 2019

\begin{tabular}{lccc}
\hline \multicolumn{1}{c}{ Variabel } & $\mathbf{n}$ & Rerata $\mathbf{H b}( \pm \mathbf{S D})$ & $\mathbf{P}$ \\
\hline Konsumsi Tanin & & & \\
$\quad$ Tepat & 30 & $10,29 \pm 1.227$ & 0,030 \\
Tidak Tepat & 26 & $9,37 \pm 1.817$ & \\
Konsumsi Kafein & & & 0,010 \\
Tepat & 47 & $10,10 \pm 1.457$ & \\
Tidak tepat & 9 & $8,64 \pm 1.746$ & \\
\hline
\end{tabular}

Berdasar tabel 5 diketahui bahwa terdapat perbedaan yang bermakna kadar hemoglobin pada responden berdasar ketepatan konsumsi zat tannin dan kafein.

Pada penelitian ini sesuai pada tabel 4 menunjukkan bahwa terdapat hubungan asupan protein, zat besi dan vitamin $\mathrm{C}$ dengan kadar Hemoglobin ibu hamil, Jumlah asupan protein yang rendah pada ibu dengan anemia lebih banyak dibandingkan dengan ibu yg mengkonsumsi cukup protein. Protein berperan penting dalam transportasi zat besi di dalam tubuh, asupan protein yang kurang akan mengakibatkan transportasi zat besi terhambat sehingga akan terjadi defisiensi zat besi yang dapat menyebabkan terjadinya keadaan anemia.[12] Hasil penelitian untuk asupan Fe menunjukkan bahwa ibu dengan asupan Fe yang kurang lebih banyak mengalami anemia dibandingkan dengan ibu yang cukup mengkonsumsi tablet Fe. Jumlah asupan Vitamin C yang cukup pada kelompok ibu dengan anemia lebih tinggi dibandingkan pada ibu tidak anemia. Hal ini sejalan dengan penelitian Yuliati, 2017 yang menyebutkan bahwa semakin tinggi kadar hemoglobin maka angka kecukupan vitamin $\mathrm{C}$ juga akan semakin tinggi.[9]

Lebih dari setengah Ibu Hamil yang menjadi responden mengalami anemia. Dilihat dari hasil penelitian asupan protein didapatkan lebih dari 50\% Ibu Hamil yang menjadi responden dalam penelitian ini masih kurang dalam mengkonsumsi asupan protein, lebih dari setengah responden masih kurang dalam mengkonsumsi asupan Fe dan lebih dari setengah responden masih kurang dalam mengkonsumsi asupan Vitamin C. Keadaan ini sungguh sangat memprihatinkan dimana zat gizi penambah kadar hemoglobin yang utama itu sendiri adalah Fe. Dalam penelitian juga didapatkan responden dengan kadar hemoglobin terendah yaitu 5,4 gr\% dimana sudah termasuk anemia berat. Penelitian oleh Fitri tahun 2015 menyebutkan mayoritas ibu hamil memiliki tingkat kecukupan zat besi dengan kategori kurang, dimana frekuensi konsumsi lauk hewani, sayuran dan buah-buahan berhubungan positif dengan bioavailabilitas besi ibu hamil.[13] Hal ini memberikan petunjuk agar petugas kesehatan terutama bidan dengan berkolaborasi dengan petugas gizi dalam memberikan konseling tentang konsumsi gizi seimbang, pentingnya suplementasi besi serta penyampaian informasi zat-zat penghambat dan yang membantu penyerapan zat besi.

Menurut hasil uji korelasi Person Product Moment terdapat hubungan yang signifikan antara asupan konsumsi protein dengan kadar hemoglobin, dengan kekuatan hubungan yang positif yaitu 0.300. Hasil analisis hubungan antara variabel asupan zat besi (Fe) dengan kadar hemoglobin didapatkan terdapat hubungan yang signifikan antara asupan konsumsi zat besi (Fe) dengan kadar hemoglobin, dengan kekuatan hubungan yang positif yaitu 0.326. Sedangkan untuk hasil analisis asupan vitamin $\mathrm{C}$ itu sendiri terdapat hubungan yang signifikan antara 
asupan konsumsi vitamin $C$ dengan kadar hemoglobin, dengan kekuatan hubungan yang negatif yaitu -0.272 .

Berdasarkan tabel 4 dapat disimpulkan terdapat hubungan yang signifikan antara asupan konsumsi protein dengan kadar hemoglobin, dengan kekuatan hubungan yang positif yaitu 0.300, artinya semakin tinggi asupan konsumsi protein maka akan semakin tinggi pula kadar hemoglobin ibu. Kekuatan hubungan yang diperoleh masuk dalam kekuatan hubungan yang lemah, yaitu 0.300. Terdapat hubungan yang signifikan antara asupan konsumsi zat besi (Fe) dengan kadar hemoglobin, dengan kekuatan hubungan yang positif yaitu 0.326, artinya semakin tinggi asupan zat besi (Fe) maka semakin tinggi pula kadar hemoglobin ibu. Kekuatan hubungan yang diperoleh masuk dalam kekuatan hubungan yang lemah, yaitu 0.326. Kekuatan hubungan lemah pada hasil di sini dapat dilihat karena ketepatan konsumsi zat tanin dan kefein yang juga bisa mempengaruhi kadar hemoglobin. Terdapat hubungan yang signifikan antara asupan konsumsi vitamin $\mathrm{C}$ dengan kadar hemoglobin Ibu Hamil dengan kekuatan hubungan yang negatif yaitu -0.272 , artinya semakin tinggi vitamin C maka semakin rendah kadar hemoglobin ibu. Kekuatan hubungan yang diperoleh masuk dalam kekuatan hubungan yang lemah. Kekuatan hubungan negatif dengan level lemah pada hasil di sini dapat dilihat karena ketepatan konsumsi zat tanin dan kefein yang juga bisa mempengaruhi kadar hemoglobin. Penelitian ini sejalan dengan penelitian Habibie (2018), yaitu tidak ada hubungan antara asupan vitamin $C$ dengan kadar hemoglobin karena mengonsumsi sumber vitamin $C$ tidak diimbangi dengan konsumsi sumber zat besi non heme, adanya konsumsi bahan makanan penghambat penyerapan zat besi, dan bentuk bahan makanan yang masih segar sehingga serat yang terkandung di dalamnya tinggi yang akan menghambat penyerapan zat besi.

Hasil penelitian ini sejalan dengan penelitian Yuliati (2017) yaitu ada hubungan tingkat kecukupan protein dengan kadar hemoglobin dari nilai signifikansi sebesar 0,005 sehingga ada hubungan antara angka kecukupan protein dengan kadar hemoglobin, hasil koefiisen korelasi spearman 0,388 yang bera rti korelasi antara variabel angka kecukupan protein dengan kadar hemoglobin sebesar 0,388 atau cukup kuat . Karena angka koefisen korelasi hasilnya positif maka korelasi kedua variabel bersifat searah, maksudnya semakin tinggi kadar hemoglobin maka semakin baik tingkat kecukupan protein bahwa semakin baik tingkat kecukupan protein semakin baik pula kadar hemoglobin. Dalam penelitian ini juga menyatakan terdapat hubungan antara kadar hemoglobin dengan tingkat kecukupan besi. Angka koefisen korelasi hasilnya positif maka korelasi kedua variabel bersifat searah. Namun tidak sejalan hasilnya dengan Tingkat Kecukupan Vitamin C dengan kadar hemoglobin Pada Ibu hamil Trimester II dan Trimester III di Puskesmas Purwanegara 2 Kabupaten Banjarnegara Berdasarkan hasil uji korelasi pearson didapatkan ada hubungan antara angka kecukupan vitamin $\mathrm{C}$ dengan kadar Hemoglobin. Hasil koefiisen korelasi Pearson cukup kuat. Angka koefisen korelasi positif maka korelasi kedua variabel bersifat searah, maksudnya semakin tinggi kadar hemoglobin maka angka kecukupan vitamin $C$ juga akan semakin tinggi.[9] Penelitian ini sejalan mengenai kecukupan vitamin $\mathrm{C}$ dengan kadar hemoglobin dengan penelitian Oktavia dimana dalam penelitiannya menyatakan tidak ada hubungan antara kecukupan vitamin $C$ dengan kadar hemoglobin. Tidak adanya hubungan diduga karena dalam hal ini vitamin $C$ berfungsi sebagai zat yang membantu penyerapan zat besi, bukan sebagai zat yang memiliki kandungan besi. Oleh karena itu fungsi vitamin $\mathrm{C}$ ini menjadi tidak berarti apabila tidak disertai dengan konsumsi pangan sumber besi yang tinggi.[14]

Pada penelitian ini berdasarkan uji analisis independent sampel $\mathrm{T}$ test yang digunakan untuk menguji hipotesis ketepatan mengkonsumsi zat tanin dan kafein terhadap kadar hemoglobin dengan tingkat kepercayaan 95\% didapatkan hasil nilai sig sebesar 0.030 yang 
artinya nilai sig lebih kecil dari nilai $\alpha 0.030<$ dari 0.05 . Kesimpulannya bahwa terdapat hubungan yang signifikan antar ketepatan mengkonsumsi zat tanin terhadap kadar hemoglobin. Dapat dilihat dari rata-rata kadar hemoglobin ibu yang tepat dalam mengkonsumsi zat tanin lebih banyak (10.29) dibandingkan rata-rata kadar hemoglobin ibu yang tidak tepat dalam mengkonsumsi zat tanin (9.37). Karena data homogen maka hasil sign yang dibaca yaitu Equal variances assumed. Pendapat Sirajuddin dan Tim tahun 2015 memperkuat hasil analisis penelitian ini yaitu penghambat penyerapan zat besi jenis teh termasuk penghambat zat besi yang sering dikonsumsi oleh responden, karena merupakan minuman yang saat ini sangat digemari oleh anak-anak serta masyarakat karena mudah didapatkan dengan harga relatif murah.[15]

Hasil analisis ketepatan konsumsi zat kafein terhadap kenaikan kadar hemoglobin ibu hamil trimester III didapatkan dengan nilai sign sebesar 0.010 artinya terdapat hubungan antara ketepatan konsumsi zat kafein terhadap kenaikan kadar hemoglobin ibu hamil trimester III. Kesimpulannya semakin tepat konsumsi zat kafein maka semakin tinggi kadar hemoglobin ibu hamil. Menurut penelitian Pratiwi tahun 2018 menyatakan ibu hamil dengan kebiasaan sering mengkonsumsi sumber pangan inhibitor zat besi sebagian besar mengalami anemia. Sedangkan pada ibu hamil yang jarang dan tidak pernah mengkonsumsi sumber pangan inhibitor zat besi sebagian besar mengalami anemia lebih rendah, di mana inhibitornya tersebut termasuk mengkonsumsi kopi dan teh[10]. Penelitian oleh Riswanda menyebutkan setiap 1 gr Tanin dapat menghambat penyerapan penyerapan konsentrasi zat besi 0,00687 gr/dl and 0,123 gr/d.[16] Teh dan kopi mengandung tanin dan kafein yang dapat mengikat mineral- mineral seperti zat besi.[17]

\section{Kesimpulan}

Terdapat hubungan asupan protein $(p=0,024)$, zat besi $(p=0,014)$ dan vitamin $C$ sebesar $(p=0,043)$. Semakin tinggi asupan protein, $\mathrm{Fe}$, vit $\mathrm{C}$, serta semakin tepat konsumsi zat tanin dan kafein maka semakin tinggi kadar hemoglobin.

\section{Referensi}

[1] P. Sarwono, Ilmu Kebidanan. Jakarta : PT Bina Pustaka Sarwono Prawirohardjo, 2014.

[2] Supariasa. IDN, Penilaian Status Gizi. Jakarta : Buku Kedokteran ECG, 2001.

[3] W. H. A. Global dan N. Targets, "Box 1: What is anaemia?," hal. 1-7, 2012.

[4] Dinas Kesehatan DIY, “1 Profil Kesehatan DIY 2016," Dinas Kesehat. DIY, hal. 180, 2016.

[5] Dinas Kesehatan DIY, "Profil DIY 2017," 2018 : 1-4. Diakses dari http://www.depkes.go.id/resources/download/profil/PROFIL_KES_PROVINSI_2017/14_DIY 2017.pdf

[6] D. K. Diy, "Tahun 2016 Kata Pengantar," no. 0274.

[7] T. B. Elema, K. B. Yimam, F. C. Waka, dan B. N. Olana, "Folate and Vitamin B-12 status of anemic pregnant women and association to hemoglobin during antenatal care, 17-37 weeks in Ambo Hospital, Oromia, Ethiopia, a multi regression analysis of socio-economic and serum folate and Vitamin B-12," J. Nutr. Hum. Heal., vol. 02, no. 01, 2018, doi: 10.35841/nutritionhuman-health.2.1.28-34.

[8] D. Fraser dan M. Cooper, Myles Buku Ajar Bidan, 14 ed. 2009.

[9] R. A. Heny Yuliati, Laksmi Widajanti, “Vitamin C dan Suplemen Tablet Besi dengan Kadar Ibu Hamil Trimester II dan III ( Di wilayah Kerja Puskesmas Purwanegara 2 Kabupaten Banjarnegara ) Heny Yuliati *, Laksmi Widajanti **, Ronny Aruben ***) Mahasiswa 
Peminatan Gizi Kesehatan Masyarakat, FKM," J. Kesehat. Masy., vol. 5, hal. 675-682, 2017.

[10] Rachmawati Oktavia Mandasar, "Hubungan Konsumsi Asupan Protein, Zat Besi dan Vitamin C dengan Kadar Hemoglobin Pada Ibu Hamil di Desa Joho Kecamatan Mojolabar Kabupaten Sukoharjo," Universitas Muhammadyah Surakarta, 2015.

[11] S. Sastroasmoro dan S. Ismael, Dasar-dasar Metodologi Penelitian Klinis, 5th ed. Jakarta: Sagung Seto, 2014.

[12] S. Almatsier, Prinsip Dasar Ilmu Gizi. Jakarta: Gramedia Pustaka Utama, 2009.

[13] Y. P. Fitri et al., "Tingkat Kecukupan dan Bioavailabilitas Asupan Zat Besi Pada Ibu Hamil di Kota Tangerang Adequacy and Bioavailability of Iron Intake among Pregnant Women in Tangerang," J. MKMI, vol. 12, no. 3, hal. 185-191, 2016.

[14] M. Yeffi, O. Tuti, dan H. Ratih, “Hubungan kepatuhan Ibu Hamil Mengkonsumsi Tablet Fe dan Pola Konsumsi dengan Kejadian Anemia di Wilayah Kerja Puskesmas Guguk Panjang Kota Bukittinggi Tahun 2015," J. Kesehat. Stikes Prima Nusant. Bukittinggi, vol. 6, no. 2, hal. 17, 2015.

[15] S. Sirajuddin dan Masni, "Faktor Determinan Kejadian Anemia Pada Siswa Sekolah Dasar Negeri Cambaya, Kecamatan Ujung Tanah Kota Makasar," Kesehat. Masy. Nas., vol. 9, no. 3, hal. 264-269, 2015.

[16] J. Riswanda, "Hubungan Asupan Zat Besi Dan Inhibitornya Sebagai Prediktor Kadar Hemoglobin Ibu Hamil Di Kabupaten Muara Enim," Biota, vol. 3, no. 2, hal. 83, 2017, doi: 10.19109/biota.v3i2.1319.

[17] P. R. Alamsyah dan D. R. Andrias, “Hubungan Kecukupan Zat Gizi Dan Konsumsi Makanan Penghambat Zat Besi Dengan Kejadian Anemia Pada Lansia," Media Gizi Indones., vol. 11, no. 1, hal. 48, 2017, doi: 10.20473/mgi.v11i1.48-54. 